\title{
Igneous Geology of the
}

Dry Mountain Quadrangle Jefferson County, Montana

By HAROLD J. PROSTKA

CONTRIBUTIONS TO GENERAL GEOLOGY

GE OLOGICALSUR VEY B ULLETIN $1221-\mathrm{F}$

$A$ description of the petrology and

- structure of the igneous rocks along the east margin of the Boulder batholith

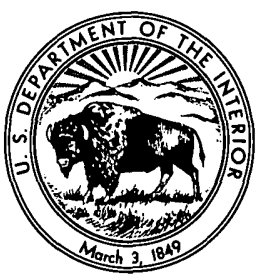


UNITED STATES DEPARTMENT OF THE INTERIOR

STEWART L. UDALL, Secretary

\title{
GEOLOGICAL SURVEY
}

\author{
William T. Pecora, Director
}

Library of Congress catalog-card No. GS66-287 


\section{CONTENTS}

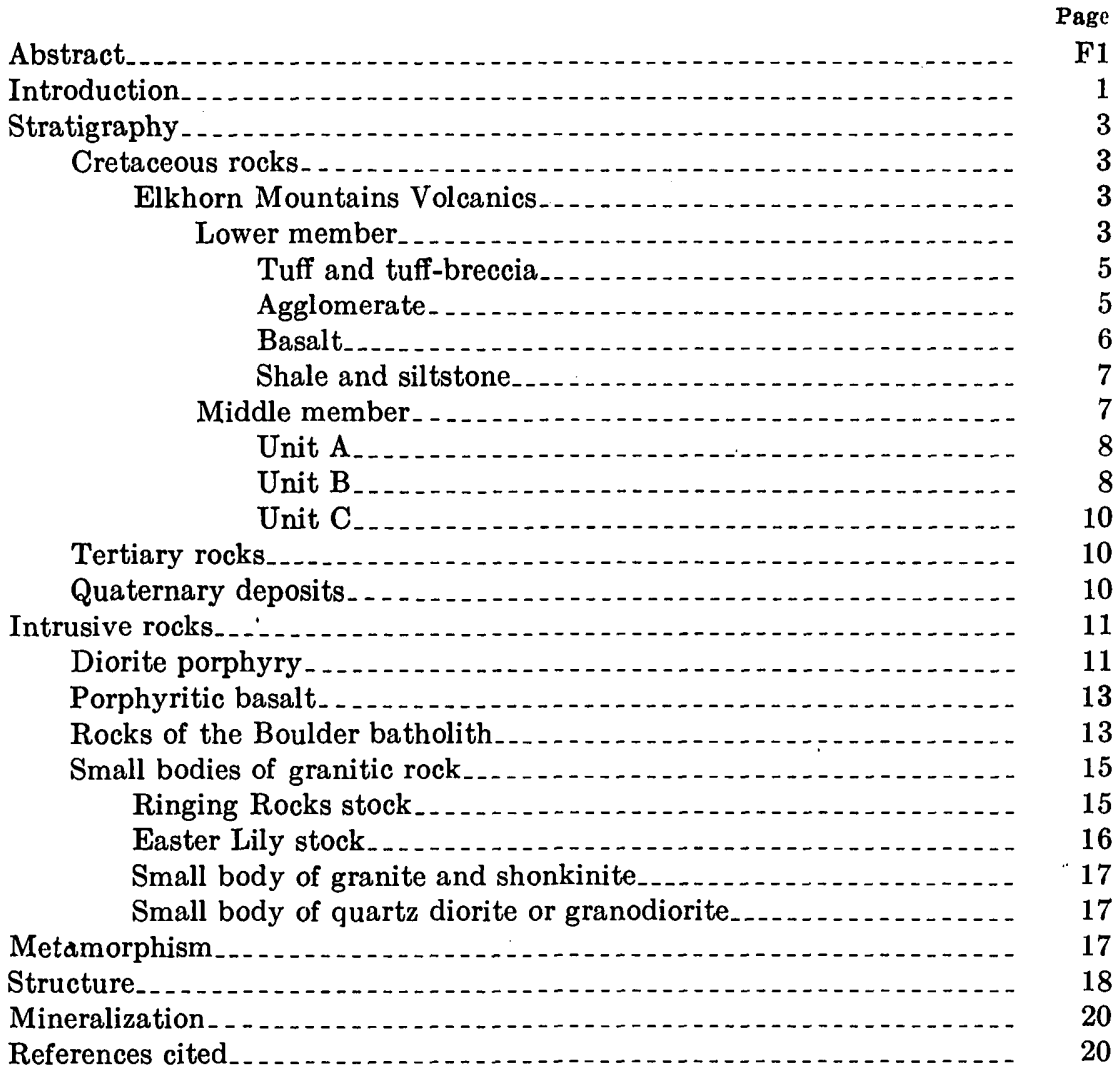

\section{ILLUSTRATIONS}

Plate 1. Geologic map of the Dry Mountain quadrangle........ In pocket

FIGURE 1. Index map showing location of Dry Mountain quadrangle _. - $\quad$ F2

2. Generalized columnar section of Elkhorn Mountains Volcanics_ 4

3. Photograph showing gentle syncline in middle member of Elkhorn Mountains Volcanics........................ 9

III 



\title{
CONTRIBUTIONS TO GENERAL GEOLOGY
}

\section{IGNEOUS GEOLOGY OF THE DRY MOUNTAIN QUADRANGLE, JEFFERSON GOUNTY, MONTANA}

\author{
By Harold J. ProstKa
}

\begin{abstract}
This report briefly describes the petrology and structure of the igneous rocks in the Dry Mountain quadrangle, an area along the east margin of the Boulder batholith southeast of Butte, Mont. The oldest rocks are the Elkhorn Mountains Volcanics of Late Cretaceous age which consists mainly of tuff, agglomerate, lava flows, and volcanic breccia, overlain by several sheets of welded tuff. About 5,700 feet of these rocks is exposed in the mapped area.

The volcanic rocks are intruded by a thick, wide'spread sheet of diorite porphyry and by several dikes and small irregular bodies of porphyritic basalt. The Elkhorn Mountains Volcanics and these hypabyssal intrusive rocks are folded into a gentle northward-plunging syncline which is cut by several steep faults. Rocks of the Boulder batholith, mainly Butte Quartz Monzonite but including aplite, pegmatite, and alaskite, intrude the west limb of the syncline. In addition, four small granitic bodies intrude the Elkhorn Mountains Volcanics and diorite porphyry.

Unconformably overlying these rocks are light-colored poorly consolidated tuffaceous lake and stream deposits of Oligocene and perhaps younger Tertiary age and alluvium, stream terrace deposits, and colluvium of Quaternary age.
\end{abstract}

\section{INTRODUCTION}

The Dry Mountain quadrangle (fig. 1) is in Jefferson County northwest of the town of Whitehall and about 25 miles southeast of Butte. The quadrangle is approximately bounded on the east by Little Whitetail Creek, and on the south by U.S. Highway 10. Dry Mountain, the south end of Ratio Mountain, and the valley of Dry Creek are the main topographic features in the quadrangle.

In the northern part of the quadrangle rugged hills underlain by igneous rocks are cut by the steep canyons of Whitetail and Dry Creeks. Southward the hills give way to broad valleys underlain by poorly consolidated Tertiary and Quaternary sedimentary rocks. Total relief in the quadrangle is about 2,500 feet.

U.S. Highway 10 crosses the southeast corner of the quadrangle. Maintained roads follow Pipestone Creek and, just east of the mapped 


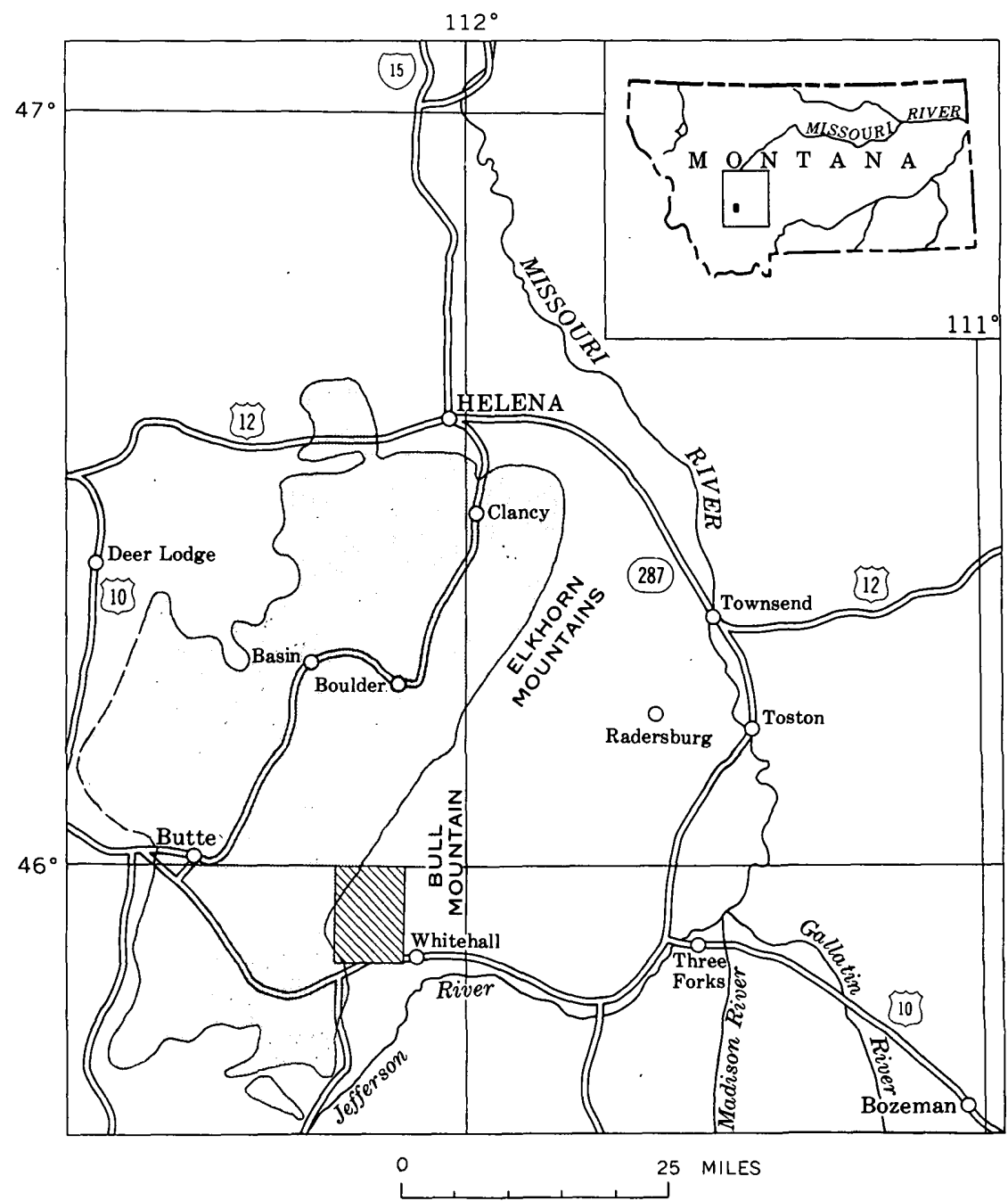

Figure 1.-Location of Dry Mountain quadrangle (lined) and Boulder batholith (stippled).

area, Little Whitetail Creek. Unimproved dirt roads provide access to much of the area away from the main roads, and the more level parts of the country can be traversed by truck or jeep.

Within the quadrangle are excellent exposures of the Elkhorn Mountains Volcanics and part of the main mass of the Boulder batholith which intrudes the volcanic rocks. The quadrangle mapping, part of a larger study of the geology and mineral deposits of the Boulder batholith and vicinity, was done primarily to study the stratigraphy, structure, and petrology of the volcanic rocks. 
Most of the detailed fieldwork was done during the summer of 1963 by the writer; general reconnaissance mapping and photogeologic work had previously been done by M. R. Klepper. Geologic data were plotted directly on a preliminary topographic base at a scale of 1: 24,000 (pl. 1).

Earlier work in this area includes a geologic map on a planimetric base at a scale of $1: 14,400$ by Burbank (1960); this map covers much of the northern third of the Dry Mountain quadrangle. Detailed geologic maps in adjoining areas have been published by Pinckney and Becraft (1961) and Alexander (1955).

\section{STRATIGRAPHY}

\section{CRETACEOUS ROCKS}

\section{BLKHORN MOUNTAINS VOLCANICS}

The oldest rocks in the quadrangle are the Elkhorn Mountains Volcanics, a thick sequence of volcanic and sedimentary rocks first named and described by Klepper, Weeks, and Ruppel (1957) for exposures in the Elkhorn Mountains some 30 miles to the northeast. These rocks can be traced nearly continuously from the type area into the Dry Mountain quadrangle. The formation is divided into lower, middle, and upper members, each unconformably overlying its predecessor (Klepper and others, 1957, p. 32). Only the upper part of the lower member and the lower part of the middle member are preserved in the quadrangle; their aggregate thickness is about 5,700 feet (fig. 2). The rocks are not sufficiently extensive to demonstrate angular discordance between the lower and middle members; however, the lowermost welded tuff of the middle member was deposited on an erosion surface cut on the lower member.

The lower member is distinctly different from the middle member and comprises dacitic to basaltic tuff, tuff-breccia, agglomerate, lava flows, siltstone, and shale. The middle member consists almost entirely of sheets of rhyolitic welded tuff.

These volcanic rocks are similar in sequence and lithology to the lower and middle members of the Elkhorn Mountains Volcanics in the type area and are direct correlatives of them. The Elkhorn Mountains Volcanics are regarded as Late Cretaceous (late Niobrara or Telegraph Creek to Judith River time) by Klepper, Weeks, and Ruppel $(1957$, p. 38). No fossils or other direct evidence of age was found in the Dry Mountain quadrangle.

\section{LOWER MEMBER}

Rocks of the lower member of the Elkhorn Mountains Volcanics are exceptionally well exposed in the low south-southwestward-trending 


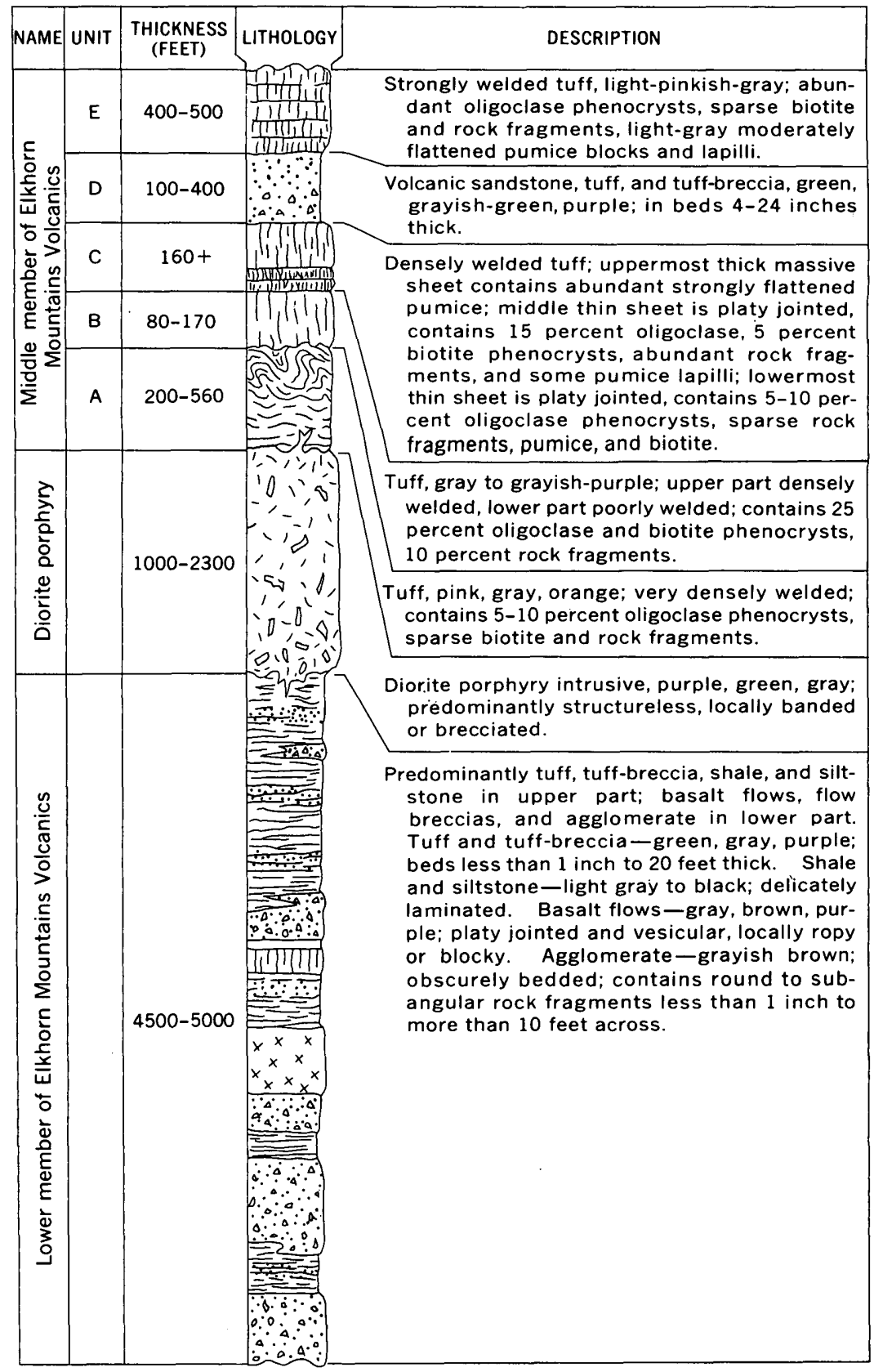

Figure 2.-Generalized columnar section of Elkhorn Mountains Volcanics in Dry Mountain quadrangle and southwestern part of Boulder quadrangle. Upper part of lower member and lower part on middle member of Klepper, Weeks, and Ruppel (1957). 
range of hills in the east-central part of the quadrangle. The descriptions which follow are mainly of these rocks. There are, in addition, several plates of tuff and tuff-breccia, the largest nearly a mile long, engulfed by diorite porphyry on Dry Mountain in the western part of the mapped area. These plates probably are septa of the lower member of the volcanics whose connection with walls or roof of the intrusive body has been eroded away. The original sedimentary features of the beds in these plates have been somewhat obscured by contact metamorphism.

The exposed lower member of the Elkhorn Mountains Volcanics in the quadrangle consists of about 45 percent tuff and tuff-breccia; 40 percent agglomerate, basalt flows, and flow breccias; and 15 percent shale and laminated siltstone. In the east-central part of the quadrangle, a maximum thickness of about 5,000 feet of these rocks is nearly continuously exposed. Tuff and tuff-breccia predominate in the upper part of the member, and agglomerate and basalt flows in the lower part. The agglomerate and basalt occur as lenses in the tuff and also as wedgelike masses that thicken eastward. In the mapped area the base of the lower member is not exposed, and the top is an erosional surface on which lies the middle member of the Elkhorn Mountains Volcanics.

The lower member is extensively intruded by a thick sheetlike body of diorite porphyry along the contact between the lower and middle members and by several smaller lensoid masses and dikes of younger porphyritic basalt.

\section{TUFF AND TUFF-BRECCIA}

Nearly half of the lower member consists of coarse- to fine-grained bedded tuff, lapilli tuff, and tuff-breccia. These rocks are green, gray, or purple and generally form crumbly, poorly resistant outcrops. Most of the coarse-grained tuff and tuff-breccia is in massive obscurely bedded units as much as 20 feet thick. In contrast, most of the finegrained tuff is in beds less than 1 inch thick; many of these beds are delicately laminated and show graded bedding and crossbedding, small-scale channeling, and soft sediment slump structures-all evidence that they were deposited and reworked by water. The tuffs are poorly sorted and consist of subangular to angular fragments of basaltic to dacitic volcanic rock and broken crystals, mainly plagioclase, in a fine-grained matrix of clay minerals, chlorite, sericite, quartz, albite, and opaque minerals.

\section{AGGLOMERATE}

Lenticular and wedgelike units of agglomerate, locally more than 200 feet thick, are mostly very obscurely bedded, and some contain 
interbeds of tuff a few inches thick. The agglomerate, which is very poorly sorted, consists of rounded to subangular rock fragmentspredominantly porphyritic dacite, andesite, basalt, and massive tuffin a fine-grained tuffaceous matrix. Most fragments are 4-12 inches in diameter; some are as much as 10 feet. In the quadrangle the only known occurrence of blocks of rock older than the Elkhorn Mountains Volcanics is in sec. 24, T. 2 N., R. 5 W., where the agglomerate contains several large blocks of quartzite and chert-pebble conglomerate which probably were eroded from exposures of Paleozoic rock east of Little Whitetail Creek or were brought up from depth in volcanic vents.

The agglomerate apparently was deposited by some mechanism of mass movement, probably mudflow. The thin interbeds of finegrained tuff may have been deposited by air or by water between successive mudflows.

\section{BASALT}

Basalt occurs as lava flows and flow breccias irregularly interlayered with agglomerate and also as thin dikes. Most of the lava flows are platy jointed and vesicular but locally are ropy and blocky. The basalt is generally medium to dark purplish gray and weathers to a punky reddish-brown rock. Locally, the basalt flows and flow breccias have been oxidized brick red and contain small fractures encrusted with hematite. These irregular, altered patches are as much as 40 feet across and were probably caused by streaming volcanic gases shortly after eruption of the basalt. They are especially abundant in secs. 12, 13, T. 2 N., R. 5 W.

Flow breccias a few feet thick and of small lateral extent are associated with the lava flows. The breccias consist of sharply angular fragments 1-6 inches across of fine-grained basalt having finer grained chilled margins; the fragments are set in a purple or brick-red matrix. These breccias are probably flow-top breccias formed by the breaking up of the chilled surface of a flow by movement of the still-molten interior.

A few basalt dikes cutting agglomerate in sec. 7, T. 2 N., R. 4 W., are petrographically identical to the lava flows but are very different from the younger, coarsely porphyritic basalt intrusives. These dikes were probably feeders for flows in the lower member.

The basalt is very fine grained and contains less than 20 percent phenocrysts of plagioclase and pyroxene; generally the phenocrysts are less than 1 millimeter long. In some flows plagioclase phenocrysts predominate, whereas in others pyroxene is more abundant. The plagioclase commonly is saussuritized, and the pyroxene is partially replaced by chlorite. The aphanitic groundmass consists of plagioclase microlites, flakes of chlorite, and minute grains of epidote, 
magnetite, hematite, and luecoxene. Vesicles are partly filled by chlorite, chalcedony, calcite, and epidote.

The agglomerate and basalt probably constitute the edge of a former volcano that stood a short distance east of the quadrangle; such a volcano is indicated by the abrupt eastward thickening of the wedgelike units of chaotically interlayered agglomerate and basalt and by the basalt dikes and the oxidized hematite-enriched patches. Four miles east of the quadrangle, on the west slope of Bull Mountain, the lower member of the Elkhorn Mountains Volcanics consists dominantly of coarse- to fine-grained tuff with minor thin flows of basalt, but no agglomerate or abrupt facies changes have been found that would suggest nearness to a volcanic vent. These relations indicate that the former volcano must have stood a short distance east of the east border of the quadrangle and that it must have been small. Remnants of the volcano probably lie buried beneath the Cenozoic sediments in the valley of Little Whitetail Creek.

SHALE AND SILTSTONE

Shale and siltstone, which make up about 15 percent of the lower member of the Elkhorn Mountains Volcanics, are probably volcanic ash which has been reworked by gentle currents in a lacustrine environment. These rocks, best exposed in the NE1/4 sec. 12, T. 2 N., R. $5 \mathrm{~W}$., are conspicuously bedded in contrast to most of the tuffs. The siltstones especially are strikingly laminated buff to black rocks showing delicate crossbedding, graded beds less than an inch thick, smallscale channeling, and load casts and other slump structures.

\section{MIDDLE MEMBER}

The middle member of the Elkhorn Mountains Volcanics consists almost entirely of sheets of strongly welded tuff deposited on an erosional surface cut on the lower member. This surface is well exposed in sec. 30, T. 3 N., R. 4 W. Rocks of the middle member underlie the south end of Ratio Mountain, where they are folded into a gentle, northward-plunging syncline that has a downfaulted east limb. The top of the middle member is not exposed in the mapped area. Total remnant thickness of this member in the quadrangle is about 850 feet.

The middle member is here divided into five units (fig. 2) but only the three lowermost units are present in the mapped area. The two uppermost units underlie the summit of Ratio Mountain less than a mile north of the quadrangle.

Most of the welded tuffs contain collapsed pumice blocks and lapilli and accessory fragments of dense volcanic rocks. Oligoclase, biotite, and magnetite occur as phenocrysts; potassium feldspar and quartz 
are present only as devitrification products. Although the welded tuffs would be classified as phenoandesites in the system of Rittmann (1952), their chemical composition is probably that of rhyolite as are most of the middle member welded tuffs in the Elkhorn Mountains (H. W. Smedes, written commun., 1965).

UNIT A

Unit $\mathbf{A}$ is a single sheet of welded tuff whose maximum remnant thickness is 560 feet. It is of variable thickness because it was deposited on an uneven erosional surface and was eroded itself before burial by the overlying sheet of welded tuff. Its color ranges from gray to shades of pink and orange. Columnar joints, locally conspicuous, are spaced about 2 feet apart near the base of the sheet and as little as 2 inches apart in the more densely welded upper part of the unit. Phenocrysts of oligoclase make up about 5-10 percent of the rock, and phenocrysts of biotite and magnetite about 1-5 percent. Pumice constitutes 10-15 percent of the rock but is difficult to recognize in the more densely welded parts of the flow.

The lowermost 60 feet or so of unit $\mathrm{A}$ has a typical eutaxitic texture, and the pumice fragments are flattened approximately parallel to the base of the unit. Upward, the pumice becomes progressively more collapsed and stretched, and the planes of flattening lie at all angles. The streaks of pumice are as much as several feet long-120-150 times longer than thick. Folds tens of feet across and many small folds are common throughout the contorted upper two-thirds of the sheet. These folds and the extreme flattening of the pumice could not be due to simple collapse alone but probably are also due to secondary flowage after the welded tuff was deposited but prior to final solidification. This secondary flowage might be due to differential compaction of the ash flow over an irregular surface or, as suggested by Smith $(1960, \mathrm{p}$. 807 ), to the sliding of the ash flow off topographic highs or to earth movements during welding of the tuff.

UNIT B

This unit is a gray to grayish-purple ash-flow tuff which has widely spaced columnar joints and which forms ledges and cliffs (fig. 3 ). The variation in thickness of this tuff, $80-170$ feet in less than half a mile, is due to its having been deposited on the eroded surface of unit $A$.

The lower 20 feet of the tuff is poorly welded and forms crumbly outcrops, but the upper part is densely welded and very resistant to weathering. This unit contains as much as 10 percent rock fragments and 25 percent biotite and plagioclase phenocrysts, more phenocrysts and fragments than any of the other welded tuffs in the quadrangle. 


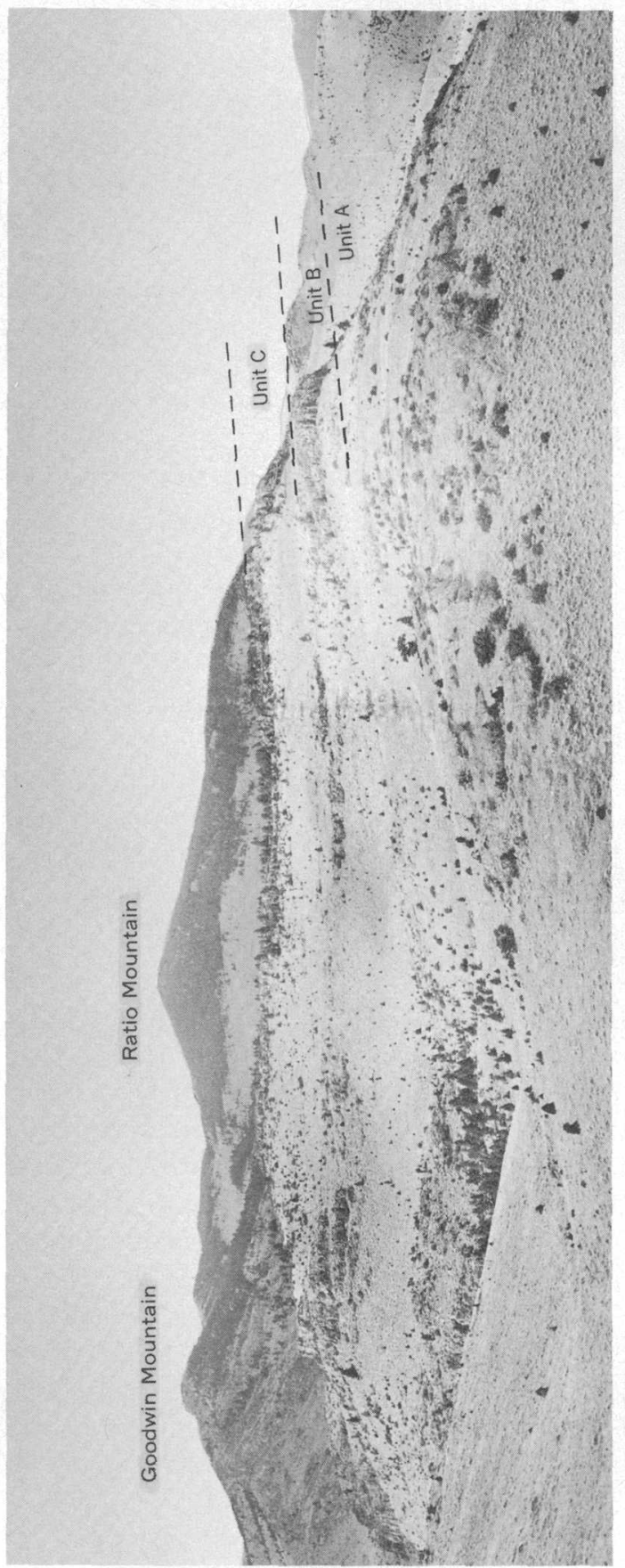

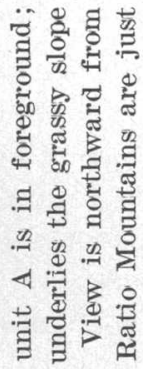

Нै

岁节节

छ

궁

进类

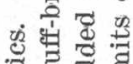

ส

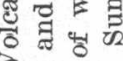

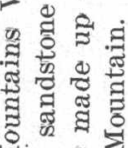

过.

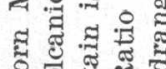

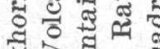

겾 $>$ ठํ

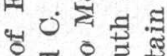

을 웧

फ

है की

क्ष 0 की

○当节 H

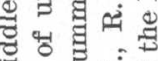

当憵安

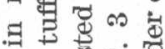

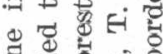

寻总

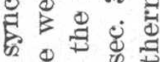

$\triangleq \tilde{\sigma}$

부워

○。

के

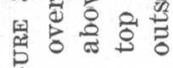

总 
UNIT $C$

This unit consists of two sheets of welded tuff, each about 30 feet thick, overlain by a massive welded tuff sheet more than 100 feet thick.

The lowermost tuff contains 5-10 percent oligoclase phenocrysts in a medium- to dark-purplish-pink groundmass. Rock fragments and biotite phenocrysts are sparse or absent. Dark-gray flattened pumice lapilli constitute less than 5 percent of the rock. This tuff is cut by very conspicuous closely spaced platy joints nearly parallel to its base.

The middle tuff is similar to the lowermost one except that it contains 5 percent phenocrysts and its platy joints are less conspicuous. This tuff contains about 15 percent oligoclase, more than 5 percent biotite, and some pale-grayish-purple pumice.

The uppermost tuff, which is pink, purple, and orange to rusty brown, contains abundant strongly flattened chunks of pumice as much as 2 inches thick and $1 / 2$ inch to 3 feet long. The average ratio of length to thickness of the pumice is about $50: 1$, which indicates that there has been some stretching due to secondary flowage (Ross and Smith, 1961, p. 25).

The ash-flow tuffs of units $\mathrm{B}$ and $\mathrm{C}$ all have planar mutual contacts and contain no interbedded sediments. The relations indicate that they were deposited in rapid succession and that there was little or no intervening erosion. The obscure, tightly welded contacts between ash flows and the extremely dense welding throughout strongly suggest that the ash flow of unit B and the three ash flows of unit C cooled as a single unit.

\section{TERTIARY ROCKS}

Poorly consolidated tuffaceous lake and stream deposits of Tertiary age-light-gray, buff, and reddish-brown sandstone, siltstone, clay, and minor conglomerate--blanket much of the topographically subdued southern part of the quadrangle. These rocks, which were deposited as sediments on a surface having several hundred feet of relief, dip a few degrees to the east and southeast and overlie the older rocks with marked unconformity. The finer grained beds contain a high percentage of partly devitrified volcanic glass. These rocks were not studied in detail, as exposures are generally poor except in the prominent bluffs near Pipestone (secs. 15, 16, 21, 22, T. 2 N., R. 5 W.), where an extensive vertebrate fauna of early Oligocene (Chadron) age was collected (Matthew, 1903; Wood and others, 1941, p. 28).

\section{QUATERNARY DEPOSITS}

Quaternary deposits include terraces of sand and gravel along the valleys of Whitetail and Little Whitetail Creeks in the northeastern 
part of the quadrangle, thick deposits of colluvium, talus, and landslide debris, and recent alluvium in the wide flood plain of Big Pipestone Creek and in the small discontinuous flood plain of Whitetail Creek.

\section{INTRUSIVE ROCKS}

The oldest intrusive rocks in the quadrangle are a large sheet of diorite porphyry and small idikes, sills, and irregular masses of porphyritic basalt. Somewhat younger rocks of the Boulder batholith and four small stocks cut the Elkhorn Mountains Volcanics and the porphyritic intrusives. Rocks of the Boulder batholith in the quadrangle are mainly Butte Quartz Monzonite, but lesser amounts of older granodiorite and younger alaskite, aplite, and pegmatite are present. The small stocks, which are described individually, consist of a wide variety of rock types.

\section{DIORITE PORPHYRY}

The oldest intrusive rock in the quadrangle is a thick sheet of diorite porphyry which underlies much of the northern part of the area. It makes up most of Dry Mountain and the lower slopes around the south end of Ratio Mountain. This intrusive is about 2,300 feet thick in the northernmost part of the mapped area, but to the south it thins and splits into several sheets interleaved with septa of country rock. This interleaving is seen in the southern part of Dry Mountain. Bedding in these septa is parallel to the regional trend, and this fact indicates that the septa were not significantly rotated during emplacement of the diorite porphyry. The porphyry was intruded into the structurally less competent rocks of the lower member of the volcanics and along the contact between the lower and middle members.

The concordant lower contact of the diorite porphyry is well exposed in the western part of sec. 12, T. 2 N., R. 5 W., and in the northern part of sec. 6, T. 2 N., R. 4 W. Thin unmapped remnants of roof rock are locally preserved in secs. 19,20 , and 29 , T. 3 N., R. 4. $\mathrm{W}$., where erosion has stripped the upper surface of the intrusive. The upper contact is extremely irregular and, although it is discordant in detail, regionally it is only slightly discordant; it cuts successively higher strata northwestward. From sec. 30, T. 3 N., R. 4 W., where the upper contact of the diorite porphyry is 300 feet below the base of the middle member of the volcanics, to the northern part of sec. 24, T. 3 N., R. 5 W., a distance of $11 / 2$ miles, the contact cuts upward 740 feet stratigraphically. Therefore, the angular discordance is about $5^{\circ}$. The body of diorite porphyry is abruptly cut off on the northwest by the Boulder batholith; to the south and east it is buried under Cenozoic depasits. 
The diorite porphyry consists of euhedral to subhedral phenocrysts of calcic labradorite zoned outward to oligoclase, accompaned by clinopyroxene and (or) hornblende in a purple, green, or olive-gray aphanitic groundmass. In thin section the groundmass is a felted aggregate of plagioclase microlites, fine-grained opaque minerals, chlorite, and probably a little potassium feldspar. Locally, the plagioclase is saussuritized, and mafic minerals are partially replaced by chlorite, quartz, calcite, magnetite, and sphene. This kind of alteration, as well as silicification, is most pronounced at the south end of Dry Mountain.

Within the diorite porphyry sheet the ratios of total phenocrysts to groundmass, of plagioclase to mafic phenocrysts, and of pyroxene to hornblende vary widely. Small, seemingly random variations occur locally, but in the body as a whole there is a marked upward decrease in the ratio of phenocrysts to groundmass, which indicates crystal settling during cooling. At the top, plagioclase phenocrysts constitute 10-15 percent of the rock, and phenocrysts of mafic minerals are sparse or absent. At the base, phenocrysts of plagioclase make up about 35 percent of the rock, and phenocrysts of mafic min. erals about 15 percent.

About two-thirds of the exposed diorite porphyry is virtually structureless; the remainder is brecciated or strongly banded, as in sec. 25 , T. 3 N., R. 5 W., and in the southern part of sec. 1, T. 2 N., R. 5 W. Banding, generally parallel to the base of the sheet, is accentuated by platy jointing. The banding is defined by color differences in the groundmass, by abrupt changes in the ratio of phenocrysts to groundmass, and by the subparallel alinement of phenocrysts.

Protoclastic breccias, consisting of angular to subrounded autoliths of diorite porphyry less than 1 inch to more than 1 foot across set in a strongly flow-banded matrix, are well exposed in the narrow ddraws of sec. 29, T. 3 N., R. 4 W., in the southern part of sec. 1, T. 2 N., R. 5 W., and at the summit of Dry Mountain. These are probably intrusion breccias formed when chilled marginal parts of the intrusive were broken by continued or resurgent pushes from the magma below. Locally, masses of iron-stained, strongly banded diorite porphyry deficient in phenocrysts are swirled into tight irregular folds. This banded rock probably crystallized from a late liquid enriched in iron and volatiles, pressed from the interior of the intrusive.

The diorite porphyry intrusives in the Elkhorn Mountains are chemically and petrologically similar to flows and tuffs in the lower member of the Elkhorn Mountains Volcanics (Klepper and others, 1957 , p. 45 ). In the Dry Mountain quadrangle as well, the diorite porphyry is compositionally and texturally similar to lithic fragments in the pyroclastic rocks it intrudes. These relationships suggest that 
intrusion occurred shortly after the Elkhorn Mountains Volcanics were deposited and that the diorite porphyry magma and pyroclastic materials in the volcanic rocks were derived from the same general source.

\section{PORPHYRITIC BASALT}

Several small dikes, sills, and lenticular and irregular bodies of dark-grayish-green seriate porphyritic basalt intrude the Elkhorn Mountains Volcanics and diorite porphyry. Most of the dikes are too small or too poorly exposed to map, but some are as much as a mile long and several hundred feet wide.

Large euhedral phenocryts of plagioclase and pyroxene constitute 10-40 percent of the rock. The plagioclase-pyroxene ratio is extremely variable in the two largest masses (secs. 16, 17, T. 2 N., R. 5 W., and sec. 32 , T. 3 N., R. 4 W.), but within the smaller bodies it is fairly uniform. In the small dikes, pyroxene phenocrysts make up as much as 20 percent of the rock. The plagioclase-rich rocks are distinctive; well-alined euhedral plates of feldspar appear lathlike when viewed on edge, but they resemble flakes of oatmeal when viewed in cross section. Plagioclase phenocrysts make up as much as 45 percent of these rocks.

\section{ROCKS OF THE BOULDER BATHOLITH}

The small part of the Boulder batholith within the Dry Mountain quadrangle consists of four main units: (1) medium-gray mediumgrained granodiorite which has not been formally named, (2) Butte Quartz Monzonite, (3) two dikelike bodies of dark-gray mediumgrained quartz monzonite, and (4) dikes and irregular bodies of alaskite, pegmatite, and aplite.

The medium-gray medium-grained granodiorite makes up a major part of the Boulder batholith just west of the mapped area. Two small salients of this large mass barely extend into the southwest corner of the quadrangle. The rock is equigranular and consists of about 50 percent plagioclase zoned from calcic labradorite to oligoclase, 15 percent potassium feldspar, 20 percent quartz, 6 percent biotite, 7 percent hornblende, and 2 percent opaque and accessory minerals.

The Butte Quartz Monzonite underlies about 4 square miles of the northwest corner of the quadrangle. It is a light-gray medium- to coarse-grained equigranular rock composed of about 35 percent andesine, 30 percent potassium feldspar, 20 percent quartz, 15 percent combined biotite and hornblende, and minor amounts of magnetite, apatite, sphene, and zircon. Megacrysts of potassium feldspar as much as 3 centimeters long occur locally, and medium- to fine-grained basic inclusions as much as 20 centimeters across occur sparsely throughout. 
Detailed mapping to the west has shown that the Butte Quartz Monzonite is younger than the granodiorite (M. R. Klepper, oral commun., 1963).

The two dikelike bodies of dark-gray medium-grained quartz monzonite intrude the Butte Quartz Monzonite near the east border of the batholith. The rocks consist of about 35 percent andesine, 35 percent potassium feldspar, 15 percent quartz, and 15 percent mafic minerals, principally biotite. The biotite, which is very distinctive, occurs as clumps as much as 1 centimeter across and as minute flakes peppered throughout the rock. The contacts of the quartz monzonite are vertical and knife sharp; the dike rock is not chilled at the contaot. The larger dike, about half a mile west of, and parallel to, the border of the batholith, is more than 3 miles long and 400-850 feet wide. The smaller dike is at the batholith contact, and for more than 2 miles it separates hornfels and granofels wallrock from Butte Quartz Monzonite. In the SE1/4 sec. 28 , T. 3 N., R. 5 W., this smaller dike splits into two prongs separated by a wedge of contact migmatite consisting of sheared granofels intimately invaded and partly replaced by aplite and fine-grained quartz monzonite.

The dikes and irregular bodies of alaskite, pegmatite, and aplite intrude the earlier batholith rocks and hornfels near the batholith border. These light-colored felsic intrusive rocks consist of about 45 percent potassium feldspar, 35 percent quartz, 20 percent sodic oligoclase, and 1 percent or less of biotite and magnetite. The larger bodies are dominantly medium- to coarse-grained equigranular alaskite locally containing small volumes of coarse pegmatite. The dikes and smaller bodies are mainly aplite and pegmatite.

The batholith-wallrock contact is nearly vertical. There is no noticeable change in texture or composition of the granitic rocks toward the contact. The wallrocks, however, are pervasively sheared near the contact, which suggests that the east margin of the batholith was intruded along a preexisting zone of shearing (M. R. Klepper, oral commun., July 1963). The sliver of hornfelsed welded tuff at the contact in secs. 27,28, T. 3 N., R. 5 W., was probably faulted into place during this early period of deformation. The strongly sheared wallrocks favored small-scale invasion of the magma as is shown by the sill-like apophyses of quartz monzonite, the dikes and lenses of aplite, and the wedge of contact migmatite. In addition, there is extensive feldspathization and silicification of hornfels as much as 200 feet from the contact in secs. 4, 5, 8, T. 2 N., R. 5 W. This "granitized" hornfels or granofels superficially resembles the finer grained batholith rocks.

The Boulder batholith is of Late Cretaceous or early Tertiary age. It intrudes the Elkhorn Mountains Volcanics of Late Cretaceous age 
and is overlain by early Oligocene sedimentary rocks southwest of Pipestone and by postbatholithic volcanics of Eocene age (Smedes and Thomas, 1965), farther north. According to published radiogenic age determinations (Chapman and others, 1955; Gottfried and others, 1959 ; Knopf, 1956, 1964), the batholith rocks are 61-87 million years old. Unpublished potassium-argon determinations of biotite-hornblende pairs indicate ages of 70-74 million years for Butte Quartz Monzonite and 74-75 million years for the unnamed granodiorite in the south western part of the quadrangle. These ages were determined by R. F. Marvin and J. D. Obradovich of the U.S. Geological Survey.

\section{SMALL BODIES OF GRANITIC ROCK}

The diorite porphyry and Elkhorn Mountains Volcanics are intruded by four small bodies of granitic rock-the Ringing Rocks and Easter Lily stocks and small bodies of granite and shonkinite and of quartz diorite or granodiorite. Small dikes of aplite and pegmatite are associated with the stocks and. also with the small body of granite and shonkinite.

The age of these small igneous bodies is not precisely known. They cut the Elkhorn Mountains Volcanics and associated intrusive diorite porphyry but are not in contact with younger rocks. The Ringing Rocks and Easter Lily stocks lie within half a mile of the Boulder batholith and intrude rocks hornfelsed by the Butte Quartz Monzonite, yet the stocks themselves show no effects of metamorphism. These relations suggest that the small granitic bodies were less susceptible to metamorphism than the diorite porphyry or that they are the same age or younger than the Butte Quartz Monzonite. A single unpublished potassium-argon determination by R. F. Marvin and J. D. Obradovich of biotite from the mafic border of the Ringing Rocks stock has yielded an age of $78.2 \pm 3.1$ million years, which suggests that the stock is somewhat older than the Butte Quartz Monzonite.

\section{RINGING ROCKS STOCK}

The Ringing Rocks stock, at the south end of Dry Mountain in secs. 4 and 9 , T. 2 N., R. 5 W., is roughly circular and is about half a mile in diameter. Pink medium-grained quartz monzonite, which makes up the center of the stock, is partly enclosed in a crescent-shaped body of coarse-grained mafic monzonite. At the south end of the stock the mafic monzonite has weathered to a heap of irregular rusty-brown extremely tough blocks 3-12 feet across that have vibrant bell-like sounds when struck; hence their local name, Ringing Rocks.

The quartz monzonite core of the stock forms prominent rounded outcrops and is exceptionally well exposed. It consists of 29 percent 
potassium feldspar, 29 percent plagioclase zoned outward from $\mathrm{An}_{58}$ to $\mathrm{An}_{20}, 18$ percent quartz which occurs interstitially and as lobate masses, 10 percent pale-green sieve-textured hornblende, 12 percent biotite which is partly altered to chlorite and sphene, and 2 percent magnetite, apatite, sericite, and zircon.

The mafic monzonite is dark gray to black on a freshly broken surface. It consists of 28 percent strongly zoned plagioclase $\left(\mathrm{An}_{62-20}\right), 24$ percent potassium feldspar, and a variety of mafic minerals : 2 percent olivine that is largely altered to serpentine, talc, and magnetite, 12 percent hypersthene, 6 percent clinopyroxene, 10 percent biotite, and 13 percent green hornblende which rims pyroxene and also occurs as distinct subhedral grains. Minor constituents include 2 percent interstitial quartz and 1 percent each of magnetite, apatite, and actinolite. This rock has been weakly hornfelsed, presumably by the quartz monzonite core.

\section{FASTER LILY STOCK}

The Easter Lily stock, here named for the Easter Lily mine in the northwestern part of the stock, is in secs. 8 and 9, T. 2 N., R. 5 W., at the south end of Dry Mountain about half a mile south of the Ringing Rocks intrusive. The stock is irregular in outline and consists of a core of pale-pink medium- to fine-grained quartz monzonite partly surrounded on the east by a crescent-shaped body of fine-grained granodiorite. An unmapped roof pendant of dark hornfels approximately 20 by 60 feet in size is situated atop the crest of the ridge approximately in the center of the stock.

The quartz monzonite in the core consists of large crystals of labradorite zoned outward to oligoclase (35 percent), lobate masses of potassium feldspar (26 percent) and quartz (29 percent), and only minor amounts of mafic minerals ( 6 percent biotite and less than 1 percent each of magnetite and sphene). Alteration products include sericite replacement in plagioclase cores $(<1$ percent) and irregular masses of calcite (2 percent).

The more mafic eastern part of the stock is fine- to medium-grained granodiorite. Laths of calcic andesine zoned outward to oligoclase (50 percent) are enclosed by irregular masses of biotite (16 percent) and hornblende (14 percent). Potassium feldspar (10 percent) and quartz ( 7 percent) occur interstitially and as ragged replacements of the earlier minerals. Clinopyroxene, as cores in the larger hornblende grains, makes up 3 percent of the rock; magnetite, 2 percent; and apatite and sphene less than 1 percent each. 


\section{SMALL BODY OF GRANITE AND SHONKINITE}

A nearly circular composite intrusive body barely 1,000 feet across, in secs. 19 and 20, T. 3 N., R. 4 W., consists of a core of pink medium-grained granite that is almost completely encircled by darkgray olivine-rich shonkinite.

The granite is weathered and friable in outcrop. It is composed mainly of subhedral Carlsbad-twinned crystals of perthite (50 percent), laths of oligoclase (10 percent), abundant interstitial granophyre (18 percent), and irregular masses of quartz (2 percent). Mafic minerals include biotite ( 7 percent), and large phenocrysts of pyroxene or olivine (5 percent) now replaced by talc, chlorite, and a little quartz and magnetite. Sphene and apatite are the principal accessory minerals. Secondary calcite (about 5 percent) is an abundant late deuteric mineral.

Olivine-rich shonkinite rims most of the granitic core and, on the northeastern side of the intrusive, is a thin dike offshoot into the country rock. The shonkinite is a very tough dark-gray rock studded with crystals of olivine as much as 5 millimeters long. Microscopically, the rock consists of subhedral phenocrysts of olivine (35 percent) and clinopyroxene ( 5 percent), ragged books of dark-reddish-brown biotite ( 5 percent), and anhedral grains of magnetite ( 3 percent) in a groundmass comprising about equal amounts of clinopyroxene and sanidine. The minute euhedral crystals of groundmass pyroxene are enclosed by large, anhedral, interlocking grains of sanidine sprinkled with minute, needlelike crystals of apatite.

\section{SMALL BODY OF QUARTZ DIORITE OR GRANODIORITE}

A small body of medium-grained quartz diorite or granodiorite, on the west flank of Dry Mountain in the N1/2 sec. 4, T. 2 N., R. 5 W., is approximately circular and is less than 100 feet in diameter. It is coarser grained than the other small intrusive bodies and is not composite.

\section{METAMORPHISM}

All the intrusive bodies in the quadrangle have to some extent thermally metamorphosed the invaded rocks. Around the early diorite porphyry and porphyritic basalt, only a zone of hard, dense hornfels a few inches to a few feet wide is formed. Locally, the country rock is hydrothermally altered near the contact, and there has been addition of silica and carbonates. These effects are best seen in the northeastern part of the quadrangle; elsewhere this hornfelsing and alteration is masked by the strong pervasive metamorphism produced later by the Boulder batholith. 
Near the Boulder batholith the megascopic effects of metamorphism are recognized as much as 2 miles from the contact. One to two miles from the batholith the diorite porphyry and tuffs are recrystallized to tough dark fine-grained hornfelses that are commonly spotted with small segregations of calcite and (or) prehnite. The hornfelses become coarser grained and lighter in color toward the batholith and grade into medium-grained granofels at the contact. Locally, within 200 feet of the batholith, the granofels is enriched in potassium feldspar and quartz and superficially resembles the finer grained batholith rocks. Such granofels is best seen in secs. 4, 5, 8, T. 2 N., R. 5 W.

Most of the hornfels near the batholith is recrystallized diorite porphyry. Microscopically, it contains relic complexly twinned plagioclase phenocrysts in a thoroughly recrystallized groundmass that is a mosaic of potassium feldspar, quartz, oligoclase, and brown biotite.

Metamorphism produced by the Ringing Rocks and Easter Lily stocks is difficult to assess either because these intrusives invaded rocks which were already hornfelsed by the Boulder batholith or because the pervasive metamorphism by the batholith has masked any metamorphic effects that may have been produced by the stocks.

Large volumes of diorite porphyry at the south end of Dry Mountain are silicified to varying degrees and the rocks range from relatively fresh porphyry to masses that are almost entirely quartz. The well-silicified rocks are light gray and brittle, and they contain small cubes of pyrite which oxidize and stain the weathered outcrops a rusty brown.

\section{STRUCTURE}

The pre-Tertiary rocks east of the Boulder batholith from Pipestone northeastward to the northern part of the Elkhorn Mountains are folded into broad, open, doubly plunging folds which trend north to north-northeastward and which are locally complicated by faults and small tight folds (Alexander, 1955; Klepper and others, 1957; Pinckney and Becraft, 1961; Ross and others, 1955; Smedes, 1962). The Elkhorn Mountains Volcanics are preserved mainly in broad synclines. The westernmost of these synclines extends from the southern part of the Dry Mountain quadrangle to the west-central part of the Boulder quadrangle (Pinckney and Becraft, 1961) where it is truncated by the Boulder batholith.

The Elkhorn Mountains Volcanics in the Dry Mountain quadrangle are folded into a shallow northward-plunging syncline cut by several steep faults. The axis of the syncline extends from the north border of the quandrangle southward through the low range of hills in the 
eastern part of the mapped area to sec. 24, T. 2 N., R. 5 W. The west limb is represented on Dry Mountain by diorite porphyry containing large tabular northeastward-dipping septa of the lower member of the volcanics. The westward-dipping structure of the east limb is preserved by several thin unmapped remnants of roof rock in secs. 19, 20, 29 , T. 3 N., R. 4 W., on the almost completely stripped upper surface of the diorite porphyry sheet.

The "island" of diorite porphyry and tuff in secs. 23 and 24, T. 2 N., R. $5 \mathrm{~W}$., is somewhat anomalous; the diorite porphyry may be part of the large sheet, and the tuffs may constitute a septum. Alternatively, the diorite porphyry may be a small sill whose stratigraphic level of intrusion is much lower than the large sheet to the north and northwest.

The north-northeastward-trending vertical contact of the Boulder batholith probably follows a prebatholith zone of shearing (M. R. Klepper, oral commun., July 1963). This situation is suggested by the pervasive shearing and foliation present in the wallrocks, but not in the batholith, near the contact.

Several steep faults are present in the northeastern part of the mapped area. The N. $10^{\circ}$ W.-trending fault in secs. 19 and 30, T. 3 N., R. $4 \mathrm{~W}$., repeats much of the welded tuff sequence and continues northward for at least 3 miles into the Boulder quadrangle (Pinckney and Becraft, 1961). This fault, which has about 1,200 feet of vertical displacement near the quadrangle border, seems to die out southward.

The N. $8^{\circ}$ E.-trending fault in secs. 1 and 12 , T. 2 N., R. 5 W., is probably pre-Oligocene, as there is no apparent offset of the Tertiary deposits, whereas offsetting of the volcanics indicates about 1,800 feet of vertical displacement, assuming that the base of the diorite porphyry sheet is concordant with bedding in the intruded tuffs.

A concealed northwestward-trending fault along Whitetail Creek is inferred to explain offsets of the lower contact of the diorite porphyry sheet and of a conspicuous bed of tuff-breccia in NW1/4 sec. 6, T. 2 N., R. 4 W. To the southeast, this fault seems to explain why nearly flat-lying Tertiary rocks on the west side of the stream do not cross the valley. This fault, in turn, is cut by a very young northeastward-trending fault of considerable length but small vertical displacement. In sec. 29, T. 3 N., R. 4 W., the stripped top of the diorite porphyry sheet is dropped a few tens of feet east of the fault. To the southwest, in secs. 1 and 12, T. 2 N., R. 5 W., the fault displaces Quaternary colluvium. Another indication that this fault is young is the change in character of Whitetail Creek as it crosses the fault. The stream flows through rugged canyons on the upthrown block, whereas on the downthrown block there are stream terraces. This fault prob- 
ably continues southwest to Pipestone Springs and may be related to the Recent hot spring activity there.

The net effect of these faults has been to raise the northwestern part of the mapped area throughout Cenozoic time. Lake and stream sediments of Oligocene age were deposited in the topographically lower southern part of the quadrangle. Continued deformation of the area in post-Oligocene time is indicated by the gentle southeastward dip of the Oligocene sediments and by the stepwise lowering, along faults, of the topography toward the southeast.

\section{MINERALIZATION}

Mineralization is slight throughout the quadrangle. Thin quartz veins have been prospected in the west-central part of the mapped area. The veins cut all the pre-Oligocene rocks and are for the most part quartz veins containing tourmaline and small amounts of pyrite, iron oxides, galena, and sphalerite. Generally there is little or no associated wallrock alteration.

\section{REFERENCES CITED}

Alexander, R. G., 1955, Geology of the Whitehall area, Montana: YellowstoneBighorn Research Proj. Contr. 195, 111 p.

Burbank, J. F., 1960, Geology of a southern portion of the Elkhorn Mountains Volcanics near Whitehall, Jefferson County, Montana: Princeton Univ. unpub. B.S. thesis, $82 \mathrm{p}$.

Chapman, R. W., Gottfried, David, and Waring, C. L., 1955, Age determinations on some rocks from the Boulder batholith and other batholiths of western Montana : Geol. Soc. America Bull., v. 66, no. 5, p. 607-609.

Gottfried, David, Jaffe, H. W., and Senftle, F. E., 1959, Evaluation of the leadalpha (Larsen) method for determining ages of igneous rocks: U.S. Geol. Survey Bull. 1097-A, p. 1-63.

Klepper, M. R., Weeks, R. A., and Ruppel, E. T., 1957, Geology of the southern Elkhorn Mountains, Jefferson and Broadwater Counties, Montana: U.S. Geol. Survey Prof. Paper 292, 82 p. [1958].

Knopf, Adolph, 1956, Argon-potassium determination of the age of the Boulder bathylith, Montana : Am. Jour. Sci., v. 254, no. 12, p. 744-745.

1964, Time required to emplace the Boulder bathylith, Montana; a first approximation: Am. Jour. Sci., v. 262, no. 10, p. 1207-1211.

Matthew, W. D., 1903, The fauna of the Titanotherium beds at Pipestone Springs, Montana : Am. Mus. Nat. History Bull. 19, p. 197-226.

Pinckney, D. M., and Becraft, G. E., 1961, Preliminary geologic map of the southwest quarter of the Boulder quadrangle, Montana: U.S. Geol. Survey Mineral Inv. Field Studies Map MF-187.

Rittmann, A., 1952, Nomenclature of volcanic rocks: Bull. Volcanol., ser. 2, v. 12, p. 75-102.

Ross, C. P., Andrews, D.A., and Witkind, I. J., compilers, 1955, Geologic map of Montana : U.S. Geol. Survey, scale 1 : 500,000.

Ross, C. S., and Smith, R. L., 1961, Ash-flow tuffs ; their origin, geologic relations, and identification: U.S. Geol. Survey Prof. Paper 366, 81 p. 
IGNEOUS GEOLOGY, DRY MOUNTATN QUADRANGLE, MONTANA F21

Smedes, H. W., 1962, Preliminary geologic map of the northern Elkhorn Mountains, Jefferson and Broadwater Counties, Montana: U.S. Geol. Survey Mineral Inv. Field Studies Map MF-243.

Smedes, H. W., and Thomas, H. H., 1965, Reassignment of the Lowland Creek volcanics to Eocene age : Jour. Geology, v. 73, no. 3, p. 508-510.

Smith, R. L., 1960, Ash flows: Geol. Soc. America Bull., v. 71, no. 6, p. 795-841.

Wood, H. E., 2d, and others, 1941, Nomenclature and correlation of the North American continental Tertiary : Geol. Soc. America Bull., v. 52, no. 1, p. 1-48. 